\title{
Contrastive Analysis of Place of Adjuncts in English and Persian Sentences
}

\author{
Zeynab Mirzahoseini \\ English Department, Ilam Branch, Islamic Azad University, Ilam, Iran \\ Habib Gowhary (Corresponding author) \\ English Department, Ilam Branch, Islamic Azad University, Ilam, Iran \\ E-mail: h_gowhary@yahoo.com \\ Akbar Azizifar \\ English Department, Ilam Branch, Islamic Azad University, Ilam, Iran
}

Ehsan Mirzahoseini

Islamic Education Department, Ilam Branch, Islamic Azad University, Ilam, Iran

Doi:10.7575/aiac.alls.v.6n.5p.128

URL: http://dx.doi.org/10.7575/aiac.alls.v.6n.5p.128
Received: $16 / 05 / 2015$

Accepted: 27/07/2015

\begin{abstract}
This study investigates the position of adjuncts in sentences in English and Persian languages. The numbers of 136 sentences are collected from English story books and their Persian translations. The frequencies of each position (initial, middle, final) of adjuncts are determined by Spss software and frequencies in English sentences are matched with Persian sentences. The results show that there is a meaningful difference between English and Persian regarding to place of adjuncts in sentences. In English the adjuncts are placed in initial and middle and final position, the initial and middle positions have the most frequency. In Persian the initial position is the most frequently used position. The frequency of middle position is less than initial and there is no adjunct in final position. The conclusion of this study is beneficial for translators, teachers and students that use the two languages.
\end{abstract}

Keywords: Systemic Functional Grammar, Adjunct, Interpersonal Adjunct, Experiential , Adjunct, Textual Adjunct

1. Introduction

Systemic functional grammar (SFG) is a form of grammatical description originated by Michael Halliday. It is part of a social semiotic approach to language called systemic functional linguistics. In these two terms, systemic refers to the view of language as "a network of systems, or interrelated sets of options for making meaning"; ( Halliday, M.A.K. 1994). Functional refers to Halliday's view that language is as it is because of what it has evolved to do (see Metafunction). The term "functional" indicates that the approach is concerned with the contextualized, practical uses to which language is put, as opposed to formal grammar, which focuses on compositional semantics, syntax and word classes such as nouns and verbs. For Halliday, all languages involve three generalized functions, or metafunctions: one construes experience (meanings about the outer and inner worlds); one enacts social relations (meanings concerned with interpersonal relations), and one weaves together of these two functions to create text (the wording).Halliday has tried, to develop a linguistic theory and description that is applicable to any context of human language. (Halliday, M.A.K. 2003).

System is used in two related ways in systemic functional theory. SFL uses the idea of system to refer to language as a whole. A usage that derives from Hjelmslev (Halliday, M.A.K. 2004). In this context, Jay Lemke describes language as an open, dynamic system. There is also the notion of system as, where linguistic systems are considered to furnish the background for elements of structure (Firth, J.R. 1968). In this use of system, grammatical or other features of language are considered best understood when described as sets of options. According to Halliday, "the most abstract categories of the grammatical description are the systems together with their options (systemic features), (Halliday.1994). System was a feature of Halliday's early theoretical work on language; it was regarded to be one of four fundamental categories for the theory of grammar, the others being unit, structure and class (Halliday, M.A.K. 1961). Halliday defined grammar as "that level of linguistic form at which operate closed systems" (Halliday, M.A.K. 1961). In relation to English, for instance, Halliday has described systems such as mood, agency, theme, etc. Halliday describes grammatical systems as closed, i.e. as having a finite set of options. By contrast, lexical sets are open systems, since new words come into a language all the time (Halliday, M.A.K. 1961), (Halliday, M.A.K.2004). In SFG, language is analyzed in three different ways (strata): semantics, phonology, and lexicogrammar. SFG presents a view of language in terms of both structure (grammar) and words (lexis). The term "lexicogrammar" describes this combined approach. Halliday describes his grammar as built on the work of Saussure, Louis Hjelmslev (Halliday, M.A.K.1994), Malinowski, J.R. Firth, and the 
Prague school linguists. In addition, he drew on the work of the American anthropological linguists Boas, Sapir and Whorf. His "main inspiration" was Firth, to whom he owes, among other things, the notion of language as system(Halliday, M.A.K. 1985).Systemic Functional Grammar applications can be practical not only in language teaching and learning but also in language in use. Firstly, as for language teaching and learning, the functional grammar perspective enhances the Communicative Teaching movement in the areas of cohesion, modality and theme choice. They are the main factors determining students' language usage in writing for coherence improvement, in speaking for expressing ideas fluently, in listening for understanding the speakers' choice of confirming new or old information, in reading for realizing the relationships within the passages. Teachers can benefit from the implications of Functional Grammar, too, especially in designing syllabuses. They may base on the functions of language items in the text to direct students instead of only focusing on the formation of the language structures. Unlike English, which has a rigid subject - verb - object (SVO) order, Persian is a free - word - order language which usually follows the (SVO) order. Translators have to take into account the thematic structure of the original text to preserve the implication and intention of the text producers (Hatim \& mason, 1990). Baker (1992) points out that translator generally face two main possibilities:

a. Translator may find that they can preserve the thematic patterning of the original without distorting the target text .if the elements placed in the Theme position in the source text can be placed in them position in the target text.

b. Translator may find that they cannot preserve the thematic patterning of the original without distorting the target text.

During the process of translation syntactic and semantic considerations may be given priority over the communicative consideration. There may be some ambiguities in meaning in target text while the lexical translation is considered. Adjunct constituents are very important in constructing detail of the how the verb is implemented, although they may be obligatory or optional. Adjuncts express such relation as time, place, manner, reason, condition, they are adverbial or prepositional.

\section{Methodology}

\subsection{Data}

The data used in this study are sentences which were collected from some story books and texts in English language and their translation in Persian language. The chosen stories are written by English popular writers and skillful Persian translators, so we can be sure that they are correct grammatically. These stories are popular among people in Iran and many other countries. The adjuncts which are used in these sentences are common, so we are familiar with them. In this study three types of adjuncts Textual, Interpersonal and Experiential are investigated. The investigated stories are:

1. The Old man and the sea, written by Ernest Hemingway that had been published in 1996. It's Persian translation by Najaf Daryabandari published in 1984.

2. The Animal farm written by George orwell published in 1951 and it's Persian translation by Amir Amirshahi, published in 1969.

3. The story of Robinson Crusoe written by Daniel Defoe published in 1719, and it's Persian translation written by Marjan Rezaee published in 2011.

4. Alice's Adventure in wonderland written by Lewis Carroll, 1865 and it's Persian translation by Hasan Honarmandi published in 1959.

5. The story of Huckleberry Fin written by Mark Twain published in 1884, and it's Persian translation written by Najaf Daryabandari published in 1987.

Most of these 136 sentences or clauses are declarative, and have adjunct. This study investigates the type and place of the adjuncts in English sentence/clauses and type and place of adjuncts in their Persian equivalents. In this study, we want to know whether Persian adjuncts are similar to English adjuncts in terms of their type and position in the sentences.

\subsection{Procedures}

The sentences which have adjunct and their equivalents are picked up and are written separately to be analyzed. The English sentences are juxtaposed with Persian sentences one by one. Then, based on Halliday Model (2004), they are described and characterized. The following steps are taken to analyze and describe the data:

1. The sentences of English language and their Persian translations are matched with each other.

2. The place of adjuncts within English sentences is compared with place of their equivalents in Persian sentences.

3. The percentage of those equivalents which are in the same position and the percentage of those which are not in the same position are determined.

4. The linguistic representation of adjuncts in English and Persian are determined.

5. The data are analyzed by both descriptive and analytic statistics.

6. The descriptions are tabulated based on SPSS software. The results are obtained by chi-square test. The frequency of type of adjuncts, place of adjuncts, manner of expressing in both languages (English and Persian) are determined.

7. The differences and the similarities are fully described and analyzed.

8. Based on frequency of similarities and differences, we answer the research questions.

\section{Results}

The research question addresses the position of adjuncts in English sentences and their Persian translations. According to the syntactic position that can be occupied by an adjunct, three different places are identified which are: initial 
position, medial position and final position. In the table (1), adjuncts in different positions (initial, middle and final) in English sentences are presented.

Table 1. The frequency of adjuncts regarding their position in English sentences

\begin{tabular}{cccc}
\hline & & frequency & percent \\
\hline \multirow{3}{*}{$\begin{array}{c}\text { Place of adjuncts in English } \\
\text { sentences }\end{array}$} & init & 60 & 44.1 \\
\cline { 2 - 4 } & mid & 58 & 42.6 \\
\cline { 2 - 4 } & fin & 18 & 13.2 \\
\cline { 2 - 4 } & sum & 136 & 100.0 \\
\hline
\end{tabular}

The above table shows that from the total number of 136 adjuncts, $\% 44.1$ are in initial position $\% 42.6$ are in middle position and \%13.2 are in final position in English sentences. The following figure states the same information.

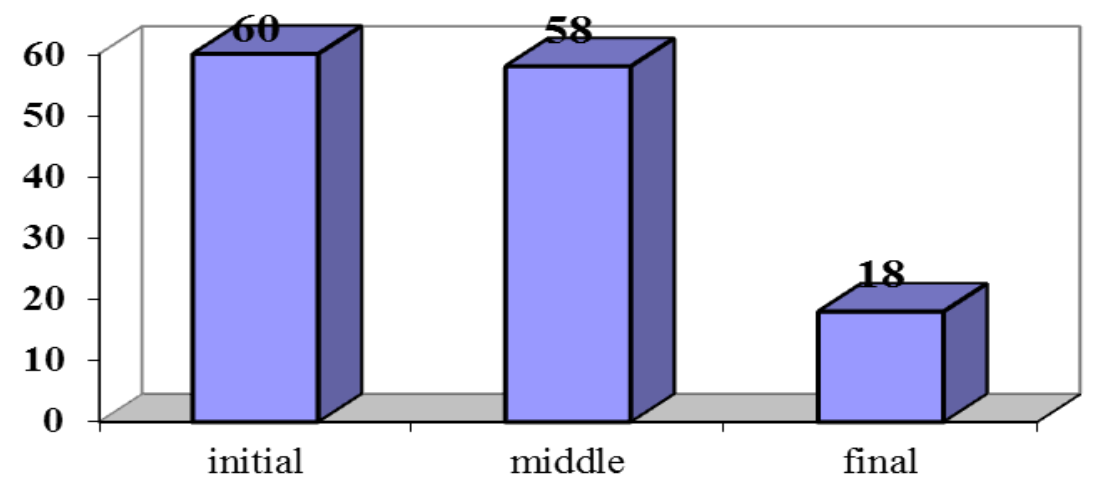

Figure 1. The frequency of adjuncts regarding their position in English sentence

In the table (2), The Persian adjuncts based on their position (initial, middle and final) are presented.

Table 2. The frequency of adjuncts regarding their position in Persian sentences

\begin{tabular}{cccc}
\hline & & frequency & percent \\
\hline \multirow{3}{*}{\begin{tabular}{c} 
place of adjuncts in Persian $\begin{array}{c}\text { init } \\
\text { sentences }\end{array}$ \\
\cline { 2 - 4 }
\end{tabular}} & $\begin{array}{c}\text { mid } \\
\text { equivalent }\end{array}$ & 40 & 51.5 \\
\cline { 2 - 4 } & sum & 19 & 34.6 \\
\hline
\end{tabular}

The above table shows that from the total number of 136 adjuncts in Persian, $\% 51.5$ are placed initially, $\% 34.6$ are in middle position and \%14 of English adjuncts have no-equivalent in Persian sentences.

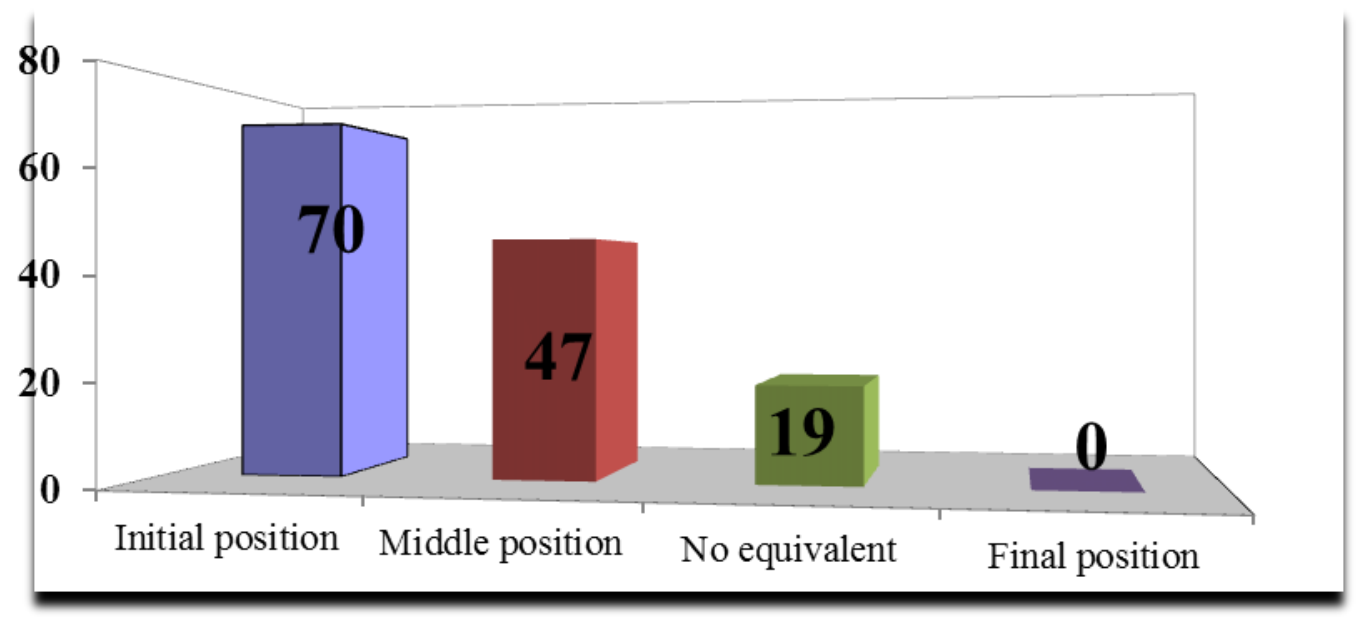

Figure 2.The frequency of adjuncts regarding their position in Persian sentences

Based on the type of adjunct, now we are going to know the frequency of adjuncts in different syntactic positions for Interpersonal, Experiential and Textual separately. Since no case was found for final position, so tables (3) shows the frequency of different types of adjuncts in initial, middle and final position in English. 


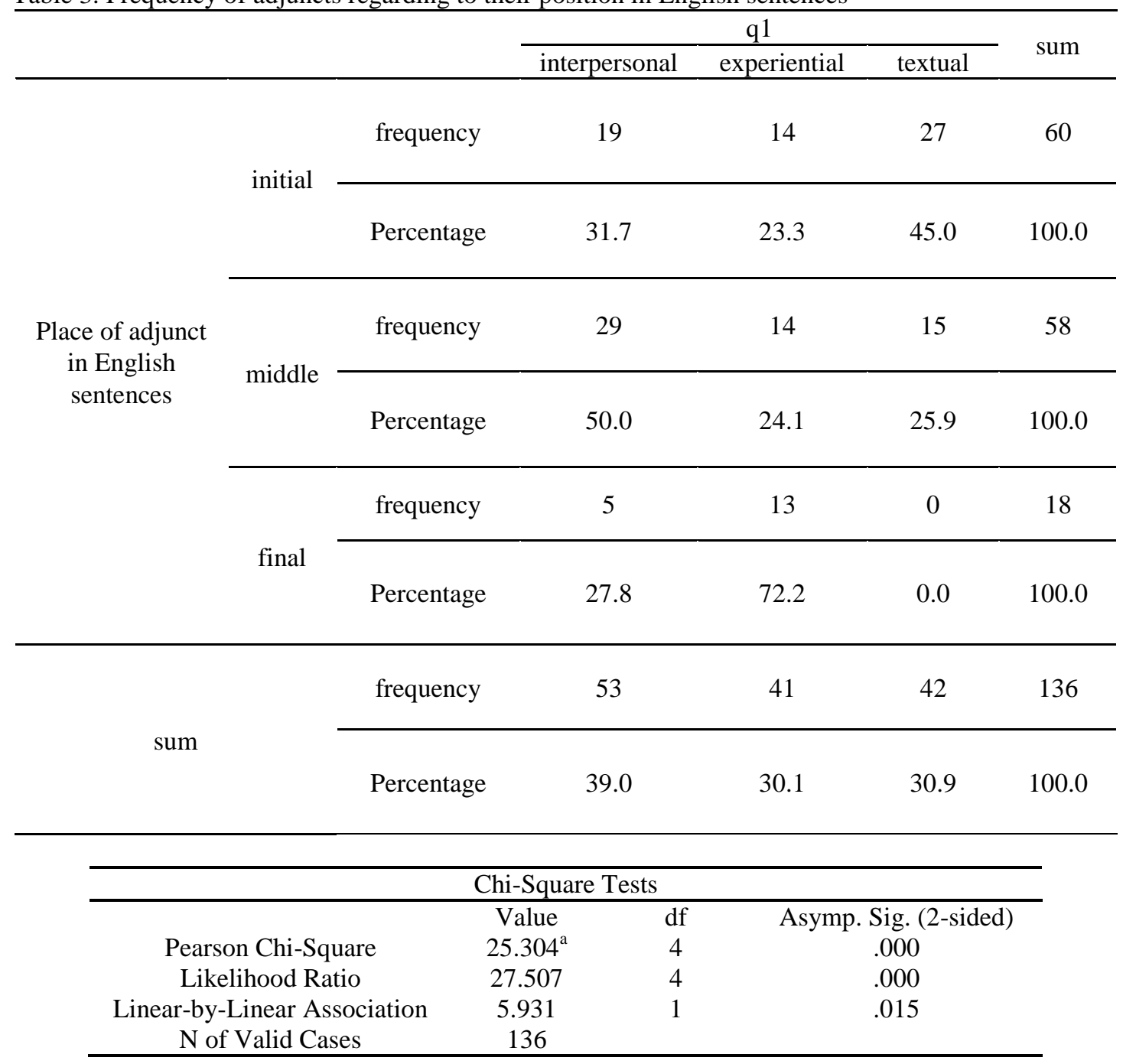

Above able shows that in English sentences, 19 cases of interpersonal adjuncts, 14 cases of experiential adjuncts and 27 cases of textual adjuncts are placed in initial position. While, 29 interpersonal adjuncts, 14 experiential adjuncts and 15 textual adjuncts are placed in middle position in English sentences. 5 cases of interpersonal adjuncts and 13 cases of experiential adjuncts were found to be in final position. There is no textual adjunct in final position in English sentences. Based on chi-square test there is meaningful difference between place of adjunct in English and Persian sentences, because the scale of $\mathrm{p}=\% 15$ that is less than specified scale $\mathrm{p}=\% 5$.Although some mismatches were found. In table (4), the frequency of adjuncts in initial and middle positions in Persian sentences is presented.

Table 4. Frequency of adjuncts regarding their position in Persian sentences

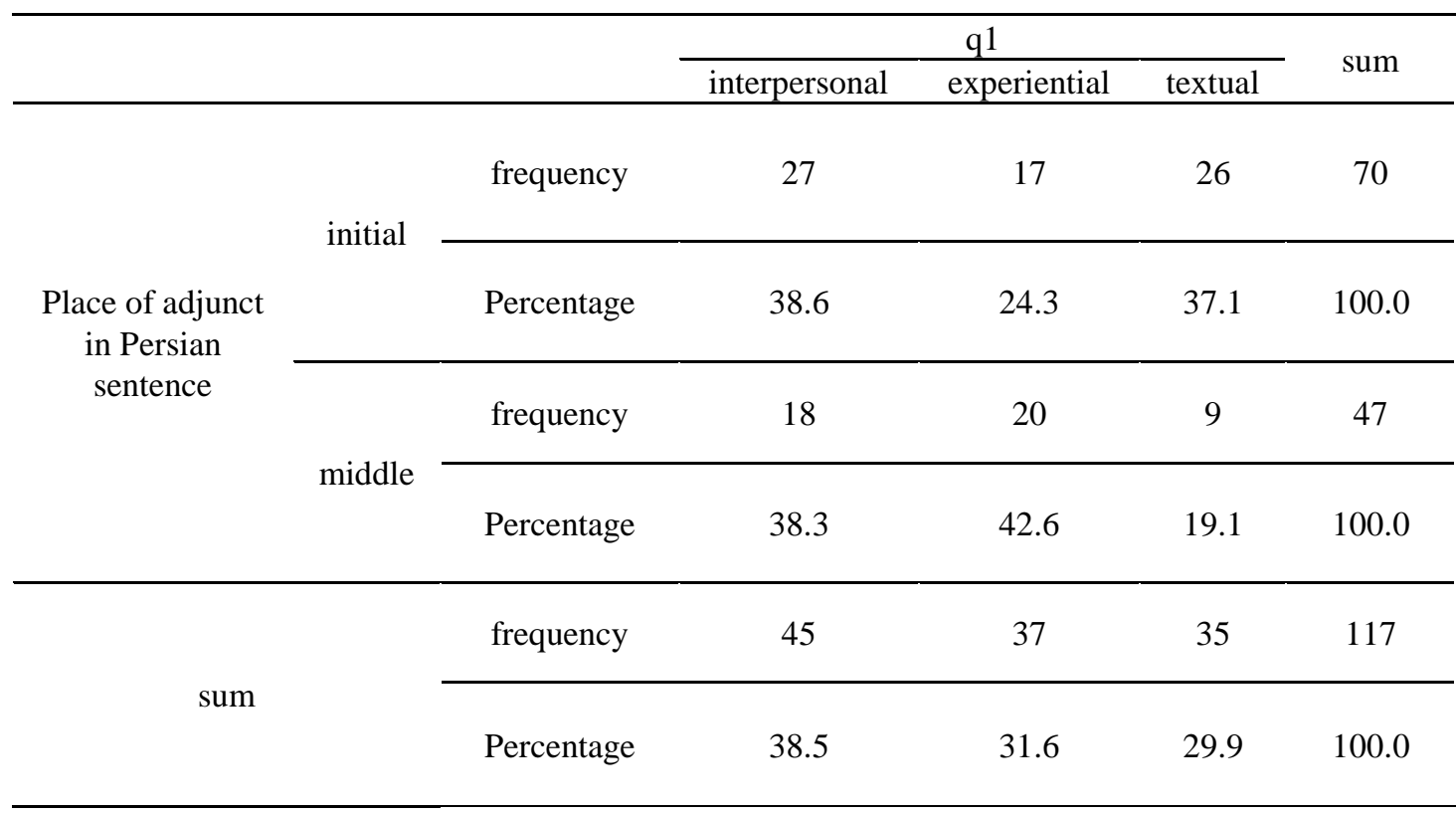


Chi-Square Tests

\begin{tabular}{cccc}
\hline & Value & df & Asymp. Sig. (2-sided) \\
\hline Pearson Chi-Square & $6.011^{\mathrm{a}}$ & 2 & .050 \\
\hline Likelihood Ratio & 6.122 & 2 & .047 \\
\hline Linear-by-Linear Association & 1.294 & 1 & .255 \\
\hline N of Valid Cases & 117 & & \\
\hline
\end{tabular}

a. 0 cells $(0.0 \%)$ have expected frequency less than 5 . The minimum expected

frequency is 14.06 .

Above table shows that in Persian \%37.1 of textual adjuncts, $\% 38.5$ of interpersonal adjuncts and \%24.3 of experiential adjuncts are placed initially. While, \%19.1 of textual adjuncts, \%38.3 of interpersonal adjuncts and \%42.6 of experiential adjuncts are placed in middle position. No adjunct in final position was found in Persian sentences.

\section{Discussion \& Conclusion}

In this study, the place of adjuncts in English and Persian is investigated and the frequencies of each position are determined and analyzed. The analyzed results show that in English the initial position is the most frequently used and the final position is the least frequently used syntactic position for adjuncts. The difference between frequency of initial and middle position is little. In Persian the initial position is the most frequently used and the middle position is the least frequently used, and there is no adjunct in final position in Persian corpus. The difference between frequency of initial and middle position in Persian language is more than same difference in English language. Some English adjuncts have no equivalent in Persian translation of those sentences neither in initial, nor in middle position. In Persian, adjuncts are tended to be located initially within a sentence. The results show that Persian language locates the adjuncts medially, although this tendency is not as much as initial position. An interesting finding of this study was that in Persian no instance of adjuncts was found finally within a sentence, although in English some adjuncts were located finally. This can be regarded as a typological difference between these two languages which must be paid attention to by translators.

In this study, the place of adjuncts in English and Persian is investigated and the frequencies of each position are determined and analyzed. The analyzed results show that in English the adjuncts are more frequently located in initial position which is higher than middle position,which is, in turn, higher than final position. The difference between frequency of initial and middle position is little. While in Persian, adjuncts like English are tended to be located initially within a sentence. The results show that Persian language locates the adjuncts medially, although this tendency is not as much as initial position. An interesting finding of this study was that in Persian no instance of adjuncts was found finally within a sentence, although in English some adjuncts were located finally. This can be regarded as a typological difference between these two languages which must be paid attention to by translators.

\section{References}

Amirshahi, A. (1969).Translation of Animal farm. Jami, Tehran, Iran.

Baker, M. (1992). In Other Words:" A Coursebook on Translation", London: Taylor and Francis Limited.

Carroll, L. (1865). Alice's Adventure in wonderland. Macmillan.

Daryabandari. N. (1984). Translation of Old man and the sea. Kharazmi, Tehran, Iran.

Daryabandari, N. (1987). Translation of Huckleberry Finn. Kharazmi, Tehran, Iran.

Defoe, L. (1719). Robinson Crusoe. W.Taylor.

Halliday, M. A. K. (1985). Introduction to functional grammar. London: Edward Arnold.

Halliday, M.A.K. (1961). Categories of the Theory of Grammar. Word, 1961, 17(3), pp241-92. Reprinted in full in Halliday, M.A.K. (---). On Grammar. Volume 1 in the Collected Works of M.A.K. Halliday. Edited by J.J. Webster. London and New York: Continuum. pp40-41.

Halliday, M.A.K. (1985). Dimensions of Discourse Analysis: Grammar. In The Handbook of Discourse Analysis, Vol 2: Dimensions of Discourse. London: Academic Press. Reprinted in full in On Grammar, Volume 1 in the Collected Works of M.A.K. Halliday. London and New York: Continuum. p262.

Halliday, M.A.K. (1985). Systemic Background. In "Systemic Perspectives on Discourse, Vol. 1: Selected Theoretical Papers" from the Ninth International Systemic Workshop, James D. Benson and William S. Greaves (eds). Ablex. Reprinted in Full in Volume 3 in The Collected Works of M.A.K. Halliday. London: Continuum. p. 188.12

Halliday, M.A.K. (1994). Introduction to Functional Grammar. London: Edward Arnold. p. 15.

Halliday, M.A.K. (2003). On the 'Architecture' of Human Language. In On Language and Linguistics, Volume 3 in the Collected Works of M.A.K. Halliday. Edited by Jonathan Webster. p. 29. 
Halliday, M.A.K., and Hasan, R. (1985). Language, context and text: Aspects of language in a social semiotic perspective. Geelong: Deakin University Press.

Halliday, M.A.K., and Matthiessen, C.M.I.M. (2004). An Introduction to Functional Grammar. Arnold.

Halliday, M.A.K. The Essential Halliday. London and New York: Continuum. Chapter 12: Metafunctions.

Hatim, B., \& Ian, M. (1990). Discourse and the Translator. London: Longman.

Hemingway, E. (1996). The old man and the sea. London Penguin Books translated by Drya bandari, N. (1984), Kharazmi, Tehran.

Honarmandi, H. (1959). Translation of Alice's Adventure in wonderland. Nil.

Orwell, G. (1945). Animal farm. Seckrand Warburg.london. England.

Rezaee, M.(2011). Translation of Robinson Crusoe. Markaz, Tehran, Iran.

Twain, M. (1884).Huckleberry Finn. Chatto \& Windus. 